\title{
Combined selection and multivariate analysis in early generations of intraspecific progenies of peanuts
}

\author{
Lucas Nunes da Luz ${ }^{*}$, Roseane Cavalcanti dos Santos², Péricles de Albuquerque Melo Filho ${ }^{3}$, \\ and Leandro Simões Azeredo Gonçalves ${ }^{4}$
}

Selection indexes are useful tools for the simultaneous selection of several descriptors aiming to promote genetic gains and a reliable advancement of segregating populations. This study tested the use of selection index of distance from the genotype to the ideotype to assist in the search for superior progenies, based on agronomic variables obtained from early generation progeny of intraspecific progenies of peanuts (Arachis hypogaea L.) Four segregating populations were used, each consisting of 90 progenies, arranged in a randomized block design with three replicates, in which the best 30 progenies of each population were selected. The index of distance to the ideotype, used for the selection, was built from a non-real model cultivar that meets the requirements for traits main stem height ( $\mathrm{SH})$, early flowering (EF), number of pegs (NP), number of pods per plant (NPP), weight of 100 pods (WP100), number of seeds per plant, and weight 100 seed (WS100). It was observed that the selection index used was effective for differentiating progenies and promoting gains at a selection pressure of $33.33 \%$. Gains were variable for the same traits in the different populations. The number of pods per plant, for example, ranged from $3.96 \%$ in the population 3 to $16.98 \%$ in the population 4 . The analysis of diversity showed that progenies selected grouped differently, by principal coordinates analysis, which corroborates the ability of the index to form groups according to traits of interest. The groups formed revealed moderate variability by the diversity analysis by the Ward/MLM method.

Key words: Arachis hypogaea, genetic gains, selection index, Ward/MLM.

\section{INTRODUCTION}

Peanut (Arachis hypogaea L.) is one of the major oilseed crops cultivated in the world, only surpassed by soybeans (Glycine max [L.] Merr.), cotton (Gossypium hirsutum L.), and rapeseed (Brassica napus L.) This crop has great commercial value because it meets demands from both the food market and food oil industry (Freitas et al., 2005). World production reached nearly 2 million tons of seeds in 2011, using about 21.7 million hectares, with an average yield of $1.7 \mathrm{t} \mathrm{ha}^{-1}$ (FAO, 2013). It is cultivated in almost all Brazilian territory, but production is concentrated in

${ }^{1}$ Universidade Estadual do Norte Fluminense Darcy Ribeiro/UENF, Laboratório de Melhoramento Genético Vegetal/LMGV, Av. Alberto Lamego, s/n, Campos dos Goytacazes, Rio de Janeiro, Brasil. *Corresponding author (lucasluzbreeder@gmail.com).

${ }^{2}$ Empresa Brasileira de Pesquisa Agropecuária (Centro Nacional de Pesquisa do Algodão)/EMBRAPA-CNPA, Rua Oswaldo Cruz 1143, Campina Grande, Paraíba, Brasil.

${ }^{3}$ Universidade Federal Rural de Pernambuco/UFRPE, Departamento de Agronomia, D. Manoel de Medeiros s/n, Recife, Pernambuco, Brasil.

${ }^{4}$ Universidade Estadual de Londrina (UEL), Departamento de Agronomia, Rodovia Celso Garcia Cid km 380, Londrina, PR 86051-900, Brasil.

Received: 9 July 2013.

Accepted: 7 December 2013.

doi:10.4067/S0718-58392014000100003 the Southeast, with more than $75 \%$ of the cultivated area (IBGE, 2012). The average grain yield, nowadays $2.7 \mathrm{t} \mathrm{ha}^{-1}$, has increased significantly over the last decade, partly due to modern commercial cultivars.

In Brazil, breeding programs of cultivated peanuts are conducted by the Instituto Agronômico de Campinas (IAC), which meets demands of the Southeast, and by Empresa Brasileira de Pesquisa Agropecuária (Embrapa), which serves the Northeast and Midwest. In the breeding program developed by Embrapa, primarily designed for semiarid regions, precocity is an additional criterion adopted for selection. It is related to the ability of plants to shorten flowering and fruit ripening, so as to decrease their exposure to environmental weathering (Santos et al., 2005).

According to the literature, higher chances of success in this segment are achieved through populations generated via intraspecific crosses, since A. hypogaea is the only commercial species of the genus. While A. hypogaea is tetraploid, its closest wild relatives are diploid. Typically, variability in peanuts is accessed via subspecies that comprise the cultivated peanut A. hypogaea. Sometimes, these subspecies come from distinct gene pools (Valls, 2005) and have additional variability that can be incorporated into breeding programs. However, increased number of crossing parents and the amount of progenies to be assessed in generations are limiting factors that require 
dynamic tools for the assessment of breeding populations.

Selection indexes (SI) are valuable tools for breeding activities of any program. Most SI categories are obtained by maximizing the correlation between the genotypic value and the index, aiming at the maximum selection efficiency. The most commonly used SI are those based on ANOVA, the predicted genotypic values, the parametric and nonparametric indices (Vieira et al., 2006; Pedrozo et al., 2009; Lessa et al., 2010; Pinto et al., 2013). The latter have been adopted by selection processes in various crops (Garcia and Souza Jr., 1999; Amaral Júnior et al., 2010; Rosado et al., 2012). The best known are the Multiplicative Index or Elston Index, $\mathrm{I}_{\mathrm{E}}$ (Elston, 1963), the Classification Sum Index, $\mathrm{I}_{\mathrm{MM}}$ (Mulamba and Mock, 1978), and the Index distance to ideotype, I I (Schwarzbach, 1972) cited by Wricke and Weber (1986).

The index distance to ideotype $\left(\mathrm{I}_{\mathrm{DI}}\right)$ has the advantage of not making assumptions about the existence of a population genotypic value to be improved and can be used in initial populations, such as $\mathrm{F}_{2}$ and $\mathrm{F}_{3}$. Another advantage over $\mathrm{I}_{\mathrm{E}}$ and $\mathrm{I}_{\mathrm{MM}}$ is that it allows the inclusion of descriptors of interest of breeders at any stage of the program, set in the ideotype targeted by the selection (Garcia and Souza Jr., 1999; Carvalho et al., 2002). Extra care must be taken when working with non-parametric indexes, to maintain population variability, since the selection of specific progeny should not contribute to decrease the levels of variability in the selected population. In programs using this type of indexes, it is important to monitor variability from the beginning of the selection cycles, so as to prevent possible losses over the program (Crossa and Franco, 2004).

The present study aimed to estimate the gains in four populations of peanuts by applying the selection index distance to the ideotype. Besides, a diversity analysis was carried out in the progenies selected via the Ward/MLM method to estimate the number of groups and the distance between these groups as a measurement of diversity in selected populations.

\section{MATERIALS AND METHODS}

The parents selected to generate working populations were chosen based on main market traits between subspecies of the genus Arachis. Four populations were generated from an intraspecific cross between cv. BR1 (A. hypogaea subsp. fastigiata) and four top lines (subsp. hypogaea). Crosses were performed using the parent 'BR1' as pollen donor. In the other parents, all female, flower buds in pre-anthesis were emasculated in the evening and the following morning the pollen of parent 'BR1' was placed on the stigma. The crossed flowers were then labeled and observed until peg emission, to confirm fruit set. All steps of crossing, obtaining of $F_{1}$ generation and $F_{2}$ seeds were conducted in a greenhouse at the Universidade Federal Rural de Pernambuco (UFRPE) in 2010.
The $F_{2: 3}$ generation was conducted in the field in the municipality of Abreu e Lima ( $07^{\circ} 54^{\prime} 43$ " S; 34 $54^{\circ} 10$ " W) Pernambuco, Brazil, in the agricultural year 2010/2011, in a randomized block design with three replicates, three lines of $4.5 \mathrm{~m}$, spaced $0.70 \times 0.30 \mathrm{~m}$, with 15 progenies each line, with six lines per population in each block. All cultural practices were performed as recommended by Santos et al. (2006). A total stand of 360 progenies were evaluated, 90 progenies per population, and the best 30 progenies were selected in each of the four populations. Average temperature and relative humidity during cultivation were $25.2{ }^{\circ} \mathrm{C}$ and $75 \%$, respectively. Rainfall was $694 \mathrm{~mm}$ for the same period.

The descriptors adopted for selection by $\mathrm{I}_{\mathrm{DI}}$ were main stem height $(\mathrm{SH})$, early flowering $(\mathrm{EF})$, number of pegs per plant (NP), number of pods per plant (NPP), weight of 100 pods (WP100), number of seeds per plant (NSP) and weight 100 seed (SW100). Plants were harvested at $90 \mathrm{~d}$ after emergence (dae) for erect genotypes and $120 \mathrm{~d}$ for runner genotypes.

The genealogy of the generated populations and the respective weights assigned to the ideotype for each population are given in Table 1 . They were defined on the basis of a non-real ideal cultivar, but considering the ascendancy of the progenies. For example, progenies of the populations 1 and 2, which belong to subsp. fastigiata, received weights consistent with the nature of the parents for the descriptors plant height and number of pegs per plant. The same was performed for all traits. It was also true for the progenies coming from subsp. hypogaea.

To obtain the $\mathrm{I}_{\mathrm{DI}}$, data were standardized and weighted by the number of traits. The index was estimated by the sum of the average Euclidean distance between different traits and the ideotype in each progeny, as described below (Equation 1). The best 30 progenies were selected in each of the four initial populations. The sum of progenies selected in each of the four initial populations gave rise to new population of 120 progenies used for diversity analysis via Ward/MLM:

$$
d_{i j}=\sqrt{\frac{1}{n}\left(\mathrm{X}_{\mathrm{ij}}-\mathrm{X}_{\mathrm{Ii}}\right)^{2}}
$$

where $d_{j i}$ is the Euclidean distance between the genotype $\mathrm{j}$ and the ideotype $I, X_{i j}$ is the measurement of the character $i$ in genotype $\mathrm{j}$ and $X_{I i}$ is the value set for the ideotype $I$ referring to the character $i$. Genotypes that reach lower index values after the sum of all the traits are considered the closest to the ideotype and, therefore, the best.

Table 1. Populations used for selection and weight of each descriptor set for the construction of the ideotype.

\begin{tabular}{llrlllrrc}
\hline Pop/Genealogy & GH & SH & EF & NP & NPP & WP100 & NSP & WS100 \\
\hline 1. BR1 $\times 280$ AM & Erect & 40 & 23 & 60 & 25 & 90 & 75 & 45 \\
2. BR1 $\times$ LBR-branco & Erect & 40 & 23 & 60 & 25 & 90 & 75 & 45 \\
3. BR1 $\times$ LViPE-06 & Runner & 20 & 26 & 70 & 35 & 120 & 60 & 60 \\
4. BR1 $\times$ LGoPE-06 & Runner & 20 & 26 & 70 & 35 & 120 & 60 & 60
\end{tabular}

GH: Growth habit; SH: stem height; EF: early flowering; NP: number of pegs; NPP: number of pods per plant; WP100: weight of 100 pods; NSP: number of seeds per plant; WS100: weight 100 seed. 
The predicted gains from selection were estimated based on the genetics parameters estimated from the generation $\mathrm{F}_{2: 3}$ evaluated in the field in the municipality of Abreu e Lima, and the selection differential obtained from the difference between the average original population and the population selected through the index. The broad sense heritability was estimated for all population in each characteristic through the genetics parameters estimated in ANOVA. We assumed that predominance for the nonadditive effects in broad sense heritability for estimate predicts gains. These analyses were carried out with the use of the Genes software system, version 2009.7.0. The analysis via Ward/MLM method was carried out using each selected progeny (120 total, sum of 30 per population) as individual, with the aid of the SAS software system (Version 9.0) for Windows (SAS Institute, 2000).

\section{RESULTS AND DISCUSSION}

Figure 1 shows the response, in new average, to the selection by $\mathrm{I}_{\mathrm{DI}}$. The diagrams show that selection was effective in bringing together the best progenies for most characters, based on averages of the original population
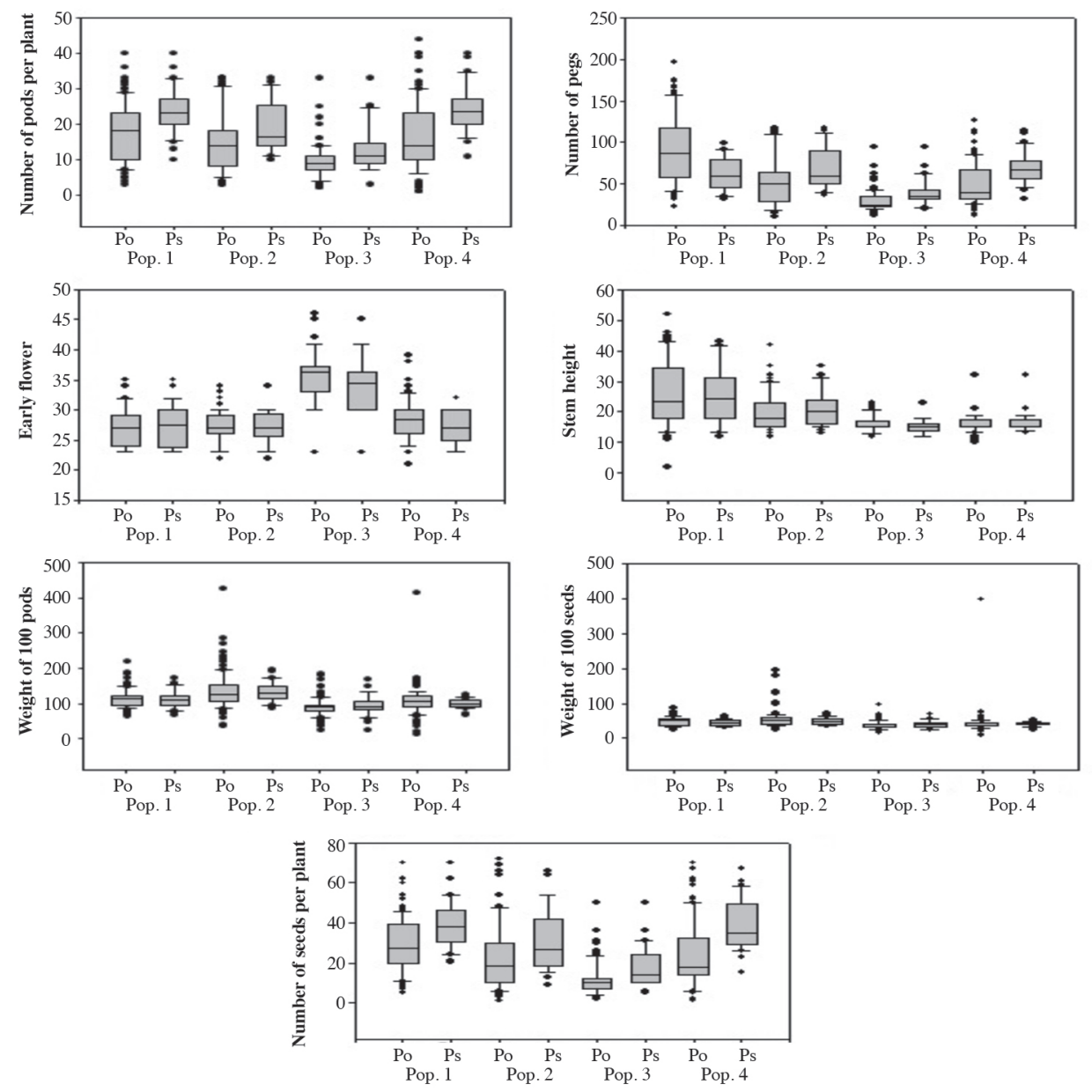

Figure 1. Box plot for the variation of seven descriptors in four $F_{2}$ populations of peanuts selected by the index of the distance to the ideotype. 
hypogaea or a subspecies derived from it. Thus, it has higher efficiency to produce pods (Luz et al., 2010).

The index distance to ideotype also contributed in the selection of earlier flowering materials in populations 3 and 4, whose progenies are often more delayed due to inheritance of runner genotypes (subsp. hypogaea). In populations 1 and $2, \mathrm{I}_{\mathrm{DI}}$ remained stable, with minor contribution of this index due to lower variability of this character among erect genotypes, which are already typically earlier. For peanuts, the selection of strains based on early flowering is of great contribution to breeding, since such character is positively correlated to the early maturation of pods and hence, to reduced cycle (Santos et al., 2005; Luz et al., 2011).

With respect to the $I_{D I}$ under study, it was observed that the index for main stem height was more responsive in populations 1 and 2, composed of erect lineages, thus presenting greater variability for height. In populations 3 and 4 , the $\mathrm{I}_{\mathrm{DI}}$ contribution was less significant due to the height of the runner plants, which do not exceed $20 \mathrm{~cm}$.

Plant height in peanuts has been indicated as a major descriptor in works on selection aiming to increase pod production. Santos et al. (2000) report a positive correlation between plant height and percentage of pegs in the main stem in erect plants, but the correlation between these two descriptors and pod production tends to be negative. However, in runner plants without pegs in the main stem, a trait of the genotype subsp. hypogaea, most pegs usually develop feasible pods. Increased average number of pegs was observed for most populations selected in this study. An exception was found in the $\mathrm{F}_{2: 3}$ progenies of population 1 and it can be explained by the already high average plant height, which hindered better reproductive efficiency in pod production.

So far, we have treated the viability of the index used to select best progenies in the population, i.e., its feasibility through weights used in the discrimination of superior progenies. However, the applicability of the index itself depends on the gains obtained by selection through it.

Table 2 shows the magnitude of the gains in percentage, in genetic predict gain, for each trait in each population. The genetic gains were estimated from heritability broad sense, assuming the prevalence of additive effects on nonadditive effects (Jogley et al., 2005; Hariprasanna et al., 2008; Emami et al., 2011). Table 2 shows that gains for the traits were quite variable in each population. For $\mathrm{SH}$, for example, there was a gain prediction of $10.9 \%$ in the average population 1 , while in population 3 , there was a loss of $-2.24 \%$ on average. These discrepancies in gains for the traits in different populations are repeated for most of them, since gains are a product of the heritability of the trait by the selection differential. In each population, heritabilities for the same traits were of different magnitudes, since they were estimated per population.

Early generations of peanuts and other crops tend to present low heritability. Luz et al. (2010) in $\mathrm{F}_{2: 3}$ peanut
Table 2. Predicted gains for seven descriptors in four populations of peanuts.

\begin{tabular}{|c|c|c|c|c|c|}
\hline & \multicolumn{5}{|c|}{ Population 1} \\
\hline & Xs & Xo & DS & $\mathrm{H}^{2}$ & G \% \\
\hline $\mathrm{SH}$ & 31.3 & 25.84 & 5.46 & 51.65 & 10.9 \\
\hline $\mathrm{EF}$ & 27.1 & 26.96 & 0.14 & 96.08 & 0.49 \\
\hline NP & 99.66 & 90.76 & 8.9 & 38.20 & 3.74 \\
\hline NPP & 19.39 & 17.64 & 1.75 & 35 & 3.47 \\
\hline WP100 & 120.67 & 114.41 & 6.26 & 30 & 1.64 \\
\hline NSP & 33.0 & 28.93 & 4.07 & 30.87 & 4.34 \\
\hline \multirow[t]{3}{*}{ WS 100} & 53.11 & 49.12 & 3.99 & 33.64 & 2.73 \\
\hline & \multicolumn{5}{|c|}{ Population 2} \\
\hline & Xs & Xo & DS & $\mathrm{H}^{2}$ & G\% \\
\hline $\mathrm{SH}$ & 20.93 & 19.85 & 1.08 & 13.90 & 0.75 \\
\hline $\mathrm{EF}$ & 27.13 & 28.26 & -1.13 & 59.90 & -2.39 \\
\hline NP & 66.30 & 51.66 & 14.6 & 35.0 & 9.89 \\
\hline NPP & 18.56 & 14.05 & 4.51 & 48.0 & 15.4 \\
\hline WP100 & 160.70 & 136.79 & 23.91 & 30.0 & 5.24 \\
\hline NSP & 34.03 & 23.11 & 10.9 & 39.0 & 18.39 \\
\hline \multirow[t]{3}{*}{ WS 100} & 60.93 & 55.12 & 5.81 & 10.91 & 1.14 \\
\hline & \multicolumn{5}{|c|}{ Population 3} \\
\hline & Xs & Xo & DS & $\mathrm{H}^{2}$ & $\mathrm{G} \%$ \\
\hline$\overline{\mathrm{SH}}$ & 14.95 & 15.76 & -0.81 & 43.59 & -2.24 \\
\hline $\mathrm{EF}$ & 34.74 & 35.78 & -1.13 & 46.17 & -1.45 \\
\hline NP & 33.63 & 29.55 & 4.08 & 42.75 & 5.90 \\
\hline NPP & 10.63 & 9.17 & 1.46 & 24.92 & 3.96 \\
\hline WP100 & 100.54 & 91.70 & 8.84 & 29.0 & 2.79 \\
\hline NSP & 14.63 & 11.61 & 3.02 & 15.91 & 4.13 \\
\hline \multirow[t]{3}{*}{ WS100 } & 38.87 & 38.66 & 0.21 & 20.82 & 1.19 \\
\hline & \multicolumn{5}{|c|}{ Population 4} \\
\hline & Xs & Xo & DS & $\mathrm{H}^{2}$ & G \% \\
\hline$\overline{\mathrm{SH}}$ & 17.33 & 16.81 & 0.52 & 40.0 & 1.23 \\
\hline $\mathrm{EF}$ & 28.37 & 28.30 & 0.07 & 32.80 & -0.08 \\
\hline NP & 61.38 & 48.45 & 12.9 & 56.58 & 15.06 \\
\hline NPP & 21.07 & 16.07 & 5 & 54.27 & 16.88 \\
\hline WP100 & 117.54 & 107.86 & 9.68 & 27.45 & 2.46 \\
\hline NSP & 32.30 & 23.41 & 8.89 & 43.88 & 16.66 \\
\hline WS 100 & 54.10 & 45.59 & 8.71 & 10.82 & 2.06 \\
\hline
\end{tabular}

SH: Stem height; EF: early flowering; NP: number of pegs; NPP: number of pods per plant; WP100: weight of 100 pods; NSP: number of seeds per plant; WS100: 100 seed weight; Xs: average of selected individuals; Xo: average of the original population; DS: selection differential; $\mathrm{H}^{2}$ : broad sense average family heritability; G\%: predicted gain.

progenies demonstrate that, for most quantitative traits related to production, such as weight of pods and seeds and number of pods, heritability was around $30 \%$. In the present work, a variation in heritability was already expected, since parents used to obtain progenies belong to distinct gene pools. Nevertheless, there were satisfactory gains for most traits assessed.

Among the traits related to production, NPP showed the highest gains, ranging from $3.96 \%$ in population 1 to $16.88 \%$ in the population 4 ; also showed consistent gains in all populations. The lowest gains were obtained for WP100 and WS100; WP100 obtained higher values $(1.64 \%)$ in population 1 and WS100 (1.14\%), in population 2. However, these low gain estimates for these traits do not mean lack of variability in the population for such traits, but are related to the formulation of the index used. For populations 1 and 2, for example, weights 90 and $45 \mathrm{~g}$ for pods and seeds, respectively, are related to the narrow acceptance range of the final product by industry. In the case of these populations, medium grains for the industry of snacks. 
Number of pegs (NP) is one of the main traits related to plant morphology. Pegs are structures similar to grains, which arise after flower fertilization and dip into the ground to generate pods. Studies show that the correlation between NPP and NP is high and positive (Santos et al., 2000; Luz et al. 2011). In populations 2 and 4, gains for NP were high, $9.89 \%$ and $15.06 \%$, respectively. In the same populations, gains for NPP were $15.4 \%$ and $16.88 \%$, respectively, thus confirming correlations presented above.

Ideotype-based selection is a little explored alternative that has received some criticism over the years, including the difficulty to find a group of traits that, together, have great impact on production (Sedgley, 1991). In this case, an analysis of correlations between descriptors can contribute to the understanding of the relationship between them, as well as their relation to production and the formation of the final product. Correlations between descriptors in peanuts are well documented in literature (Santos et al., 2000; Swamy et al., 2003; Kotzamandis et al., 2006; Luz et al., 2011) and have demonstrated to be useful for indirect selection. Thus, it is clear that there is a group of traits in peanuts, mainly correlated among them, which facilitates the construction of a model genotype. It defeats one of the criticisms to the ideotype model (Sedgley, 1991).

The $I_{D I}$ used in this study was effective in selecting the best progenies, as shown in the diagram of Figure 1, which was ratified by the real gains shown in Table 2, with selection pressure of $33.33 \%$. This selection pressure is in agreement with that described by Carvalho et al. (2002) in eggplant, $35.3 \%$. Success stories of selections using $\mathrm{I}_{\mathrm{DI}}$ were reported for passion fruit (Passiflora edulis Sims, Oliveira et al., 2008), eggplant (Solanum melongena L., Carvalho et al., 2002) and peanuts (Emami et al., 2011).

In early generations, it is necessary to ensure, besides the effectiveness of selection, that the potential selection capitalized by the index expresses itself in the form of phenotype in the next generation. For selection in early generation test (EGT), such as $\mathrm{F}_{2}$ and $\mathrm{F}_{3}$, Bernardo (2003) suggests that the effectiveness of inheritance can be assessed by the pre-existing knowledge of properties of variance components, additiveness and non-additiveness. The higher the additive effect on the traits under study, the greater the potential of the early selection for them (Padi and Ehlers, 2008; Yang, 2009).

It is known that the additive effects prevail over the non-additive in many traits of peanuts, including early flowering, size of pods and seeds, number of pods per plant, resistance to certain diseases, weight of pods and seeds, among others (Cruickshank et al., 2002; Pensuk et al., 2002; Jogley et al., 2005; Hariprasanna et al., 2008). In general, when considering the significant genetic correlations between most traits discussed here and the indication of prevalence of additive effects over the nonadditive for most descriptors evaluated here, success is expected to occur at the early selection of genotypes, since the selection of the best progenies possibly contributes to maximize variance between traits in the following generations.

Besides the selection of progenies, it was estimated the genetic diversity of populations and progenies selected through agronomic data sampled in each individual. In all, four groups were pre-defined by the likelihood function, based on the pseudo $\mathrm{F}$ and pseudo t criteria. Groups formed and respective distances between them are described in Table 3 , where we can observe differences between groups ranging from high $(2 \times 4)$ to low $(1 \times 2)$. Group 3 contained $70.6 \%$ of genotypes, while groups 1,2 , and 4 detained $13 \%, 9.2 \%$, and $9.2 \%$, respectively. Groups formed here have no relationship with the number of populations. Rather, they are an overview of the variability available in the populations allocated in groups, based on the Ward/ MLM method. The progenies selected by the index are distributed in all groups. Somehow, this strategy displays the variability of progenies in the groups.

The phenotypic averages of the quantitative variables for each group formed and the canonical variables associated to descriptors are shown in Table 4 . Coincidentally, all individuals allocated to group 1 (13 individuals) of diversity found in Table 3 are among the 30 progenies selected in population 1 . The remaining progenies are allocated in other diversity groups. The progenies selected in populations 2, 3, and 4 are dispersed by the other diversity groups, except the group with progenies of population 1 . Table 4 shows that the first two canonical variables grouped $87 \%$ of the existing variation.

In group 1 (Table 4), it is also observed that the

Table 3. Distance between groups and respective allocation of individuals in groups for 120 progenies of peanuts via Ward-MLM.

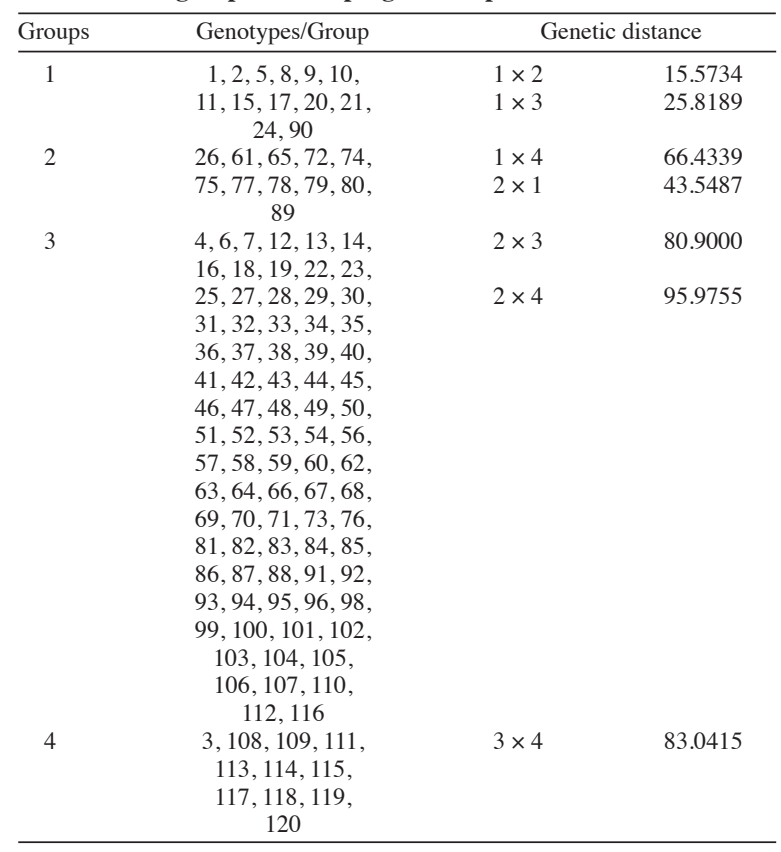


Table 4. Phenotypic average of the quantitative variables in each group formed by Ward/MLM.

\begin{tabular}{lrrrrrrr}
\hline & \multicolumn{4}{c}{ Groups } & & \multicolumn{2}{c}{ Canonical variables } \\
\cline { 2 - 4 } Descriptors & G1 & G2 & \multicolumn{1}{c}{ G3 } & \multicolumn{1}{c}{ G4 } & & VC 2 \\
\hline SH & 26.16 & 15.98 & 18.96 & 23.06 & & 0.54 & 0.32 \\
EF & 28.71 & 36.96 & 27.21 & 28.00 & & -0.25 & -0.74 \\
NP & 47.92 & 36.66 & 60.28 & 99.41 & & 0.06 & 0.77 \\
NPP & 29.00 & 10.72 & 18.80 & 31.00 & & 0.66 & 0.51 \\
WP100 & 100.98 & 99.61 & 105.72 & 119.48 & & -0.00 & 0.33 \\
NSP & 39.69 & 15.77 & 29.46 & 58.58 & & 0.46 & 0.65 \\
WS100 & 46.52 & 38.37 & 42.91 & 42.88 & & 0.25 & 0.13 \\
\hline
\end{tabular}

SH: stem height; EF: early flowering; NP: number of pegs; NPP: number of pods per plant; WP100: weight of 100 pods; NSP: number of seeds per plant; WS100: weight 100 seed.

reproductive efficiency (ER) of the selected progenies, the NPP/NP ratio, surpassed $60 \%$. This result is extremely important for breeders because it helps in the selection of materials with greater ability to transform gynophores into pods. In peanuts, despite the high amount of flowers and gynophores emitted by plants during the reproductive phase, only $25 \%$ to $30 \%$ are effective to generate viable pods; in runner plants, this percentage can reach 50\% (Santos et al., 2000; Luz et al., 2011). This percentage may be effectively raised by the selection of good parents, with high ability for this trait. In the other groups (Table 4), low magnitude was observed for the NPP/NP relation, although individuals in group 4 have higher average for
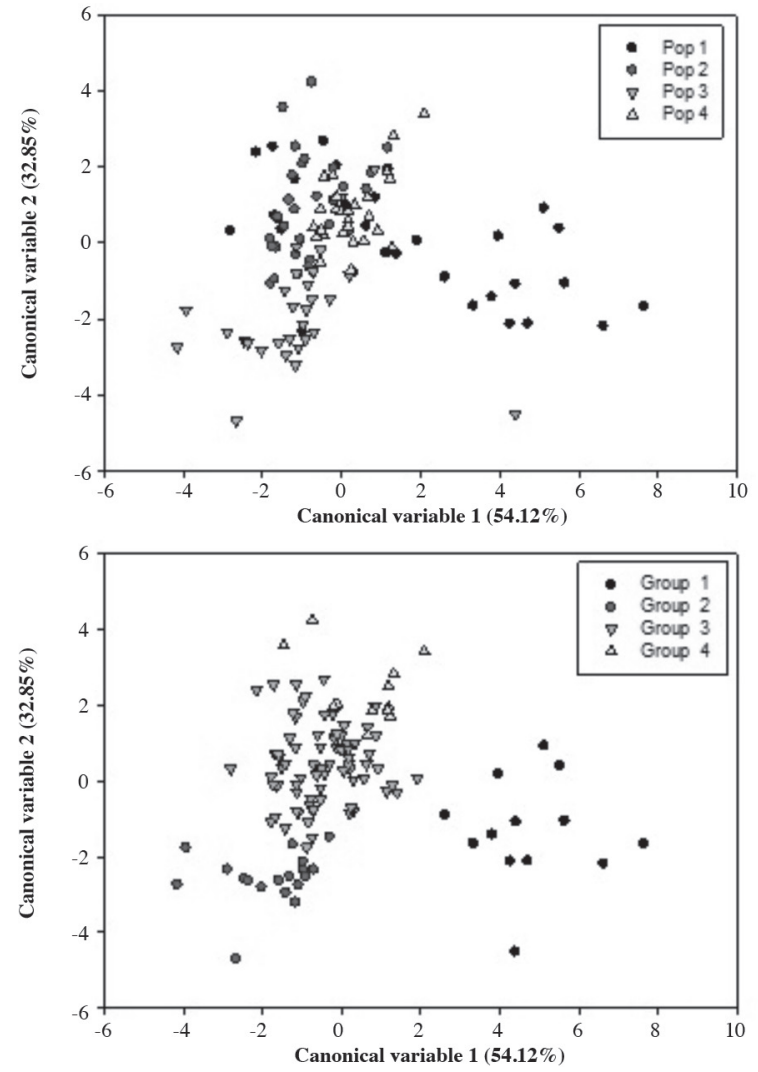

Figure 2. Representative graphic between the first two canonical variables $(86.97 \%)$ for the initial population $(2 \mathrm{~A})$ and for the four groups formed (2B). the production of pods. The dispersion of groups based on the two first canonical variables (Table 4) is shown in Figure 2A for original populations and Figure 2B for the groups formed.

The diversity analysis showed more cohesive groups, compared to selected populations. This is the case of group 1 , which was isolated from the other groups. There may be greater variability between groups than within groups. On the other hand, since the selected progenies are dispersed among the groups, it is possible to select productive and divergent progenies as those of groups 1 and 4 . At this point, the analysis of divergence performed in this study is justified and helps to mitigate a possible narrowing of the genetic base at the early stages of selection, which is another argument against selection by ideotypes.

To compose a superior genotype, a population should have not only variability for the traits, but intercommunication between them, i.e., gene blocks must be broken to be able to generate superior gene combinations. Selection via ideotype can be of great assistance in autogamous species, considering the limited possibility of gathering a large amount of favorable genes in a genotype via crosses. In these species, self-pollination is the preferential reproduction system, particularly for peanuts, since a recurrent selection program would be very costly and with little expectation of success, because the flowers are cleistogamic and there is no male sterility. Otherwise, the construction of models for plant breeding requires a broad knowledge of relationships between the descriptors adopted.

An ideotype should not be described as a single genotype, perfect for all environments, but as the idea of a model that brings together attributes that complement each other. In this case, the ideotype for a particular environment may not be suitable for another. Thus, associations of various methods of analysis that include early identification of the genetic potential of a population and selection at early stages increase the number of alternatives available to breeders and chances of success throughout the breeding program.

\section{CONCLUSIONS}

The distance to the ideotype index can be used in early generations with broad chances of success in selecting superior progenies. However, fixing the ideotype should not lead to decrease population variability. The monitoring of variability at the early cycles may lead the selection of divergent progenies besides the superior ones.

\section{ACKNOWLEDGEMENTS}

To the Brazilian Support Agency, Coordenação de Aperfeiçoamento de Pessoal em Nível Superior/CAPES and Embrapa Algodão-EMBRAPA/CNPA. 


\section{LITERATURE CITED}

Amaral Júnior, A.T., S.P. Freitas Júnior, R.M. Rangel, G.F. Pena, R.M. Ribeiro, R.C. Moraes, et al. 2010. Improvement of a popcorn population using selection indexes from a fourth cycle of recurrent selection program carried out in two different environments. Genetics and Molecular Research 9:340-370.

Bernardo, R. 2003. On the effectiveness of early generation selection in self-pollinated crops. Crop Science 43:1558-1560.

Carvalho, C.G.P., D.J.H. Silva, C.D. Cruz, and J.M.S. Viana. 2002. Selection based on distances from ideotype. Crop Breeding and Applied Biotechnology 2:171-178.

Cruickshank, A.W., M. Cooper, and M.J. Ryley. 2002. Peanut resistance to Sclerotinia minor and S. sclerotiorum. Australian Journal of Agricultural Research 53:1105-1110.

Crossa, J., and J. Franco. 2004. Statistical methods for classifying genotypes. Euphytica 137:9-37.

Elston, R.C.A. 1963. Weight free index for the purpose of ranking or selection with respect several traits at a time. Biometrics 19:85-97.

Emami, H., R. Honarnejad, and M. Esfahani. 2011. Comparing economic coefficients to select the optimum selection index in peanuts. American Eurasian Journal Agriculture \& Environment Science 10:972-977.

FAO. 2013. FAOSTAT. World production of peanuts. FAOSTAT, FAO, Rome, Italy. Available at http://faostat.fao.org/site/567/ DesktopDefault.aspx?PageID=567\#ancor (accessed November 2013).

Freitas, S.M., S.S. Martins, A.K. Nomi, e A.F. Campos. 2005. Evolução do mercado brasileiro de amendoim p. 16-44. In Santos, R.C (ed.) O agronegócio do Amendoim no Brasil. Embrapa Algodão, Campina Grande, Brasil.

Garcia, A.A.F., e C.L. Souza Jr. 1999. Comparação de índices de seleção não paramétricos para a seleção de cultivares. Bragantia 58:253-267.

Hariprasanna, K., C. Lal, T. Radhakrishnan, H.K. Gor, and B.M. Chikani. 2008. Analysis of diallel cross for some physical-quality traits in peanut (Arachis hypogaea L.) Euphytica 160:49-57.

IBGE. 2012. Levantamento sistemático da produção agrícola. Instituto Brasileiro de Geografia e Estatística (IBGE), Rio de Janeiro, Brasil. Available at http://www.ibge.gov.br/home/ estatistica/indicadores/agropecuaria/lspa/lspa_201202_5.shtm (accessed March 2012).

Jogley, S., W. Tula, and T. Kesmala. 2005. Combining ability analysis and phenotypic correlation of nodule parameters and agronomic traits in peanut (Arachis hypogaea L.) Songklanakarin Journal Science and Technology 27:213-221.

Kotzamandis, S.T., N. Stavropoulos, and G.C. Ipsilandis. 2006. Correlation studies of 21 traits in $F_{2}$ generation of groundnut. Pakistan Journal of Biological Sciences 9:929-934.

Lessa, L.S., C.A.S. Ledo, V.S. Santos, S.O. Silva, e C.P. Peixoto. 2010. Seleção de híbridos diplóides (AA) de bananeira com base em três índices não paramétricos. Bragantia 69:525-534

Luz, L.N., R.C. Santos, and P.A. Melo Filho. 2010. Estimativas de parâmetros genéticos em linhagens de amendoim baseadas em características associados ao ginóforo. Ciência Agronômica 41:132-138.

Luz, L.N., R.C. Santos, and P.A. Melo Filho. 2011. Correlations and path analysis of peanut traits associated with the peg. Crop Breeding and Applied Biotechnology 11:88-93.
Mulamba, N.N., and J.J. Mock. 1978. Improvement of yield potential of the etoblanco maize (Zea mays L.) populations by breeding for plants traits. Egypt Journal of Genetics and Cytology 7:40-51.

Oliveira, E.J., V.S. Santos, D.S. Lima, M.D. Machado, R.S. Lucena, T.B.N. Mota, et al. 2008. Seleção em progênies de maracujazeiroamarelo com base em índices multivariados. Pesquisa Agropecuária Brasileira 43:1543-1549.

Padi, F.K., and J.D. Ehlers. 2008. Effectiveness of early generation selection in cowpea for grain yield and agronomic characteristics in semiarid West Africa. Crop Science 48:533-540.

Pedrozo, C.A., F.R.G. Benites, M.H.P. Barbosa, M.D.V. Resende, and F.L. Silva. 2009. Efficiency of selection indexes using the REML/BLUP procedure in sugarcane breeding. Scientia Agraria 10:31-36.

Pensuk, V., S. Wongkaew, S. Jogloy, and A. Patanothai. 2002 Combining ability for resistance in peanut (Arachis hypogaea) to Peanut bud necrosis tospovirus (PBNV). Annals of Applied Biology 141:143-146.

Pinto, F.O., L.N. Luz, M.G. Pereira, D.L. Cardoso, and H.C.C Ramos. 2013. Metodologia dos modelos mistos para seleção combinada em progênies segregantes de mamoeiro. Revista Brasileira de Ciências Agrárias 8:211-217.

Rosado, L.D.S., C.E.M. Santos, C.H. Bruckner, E.S. Nunes, and C.D. Cruz. 2012. Simultaneous selection in progenies of yellow passion fruit using selection indices. Revista Ceres 59:95-101.

Santos, R.C., R.J.M. Custódio, and V.F. Santos. 2000. Eficiência reprodutiva em genótipos de amendoim e correlação fenotípica entre caracteres ligados ao ginóforo. Ciência e Agrotecnologia 24:617-622.

Santos, R.C., J.I. Godoy, and A.P. Fávero. 2005. Melhoramento do amendoim. p. 123-192. In Santos, R.C (ed.) O agronegócio do amendoim no Brasil. Embrapa Algodão, Campina Grande, Paraíba, Brasil.

Santos, R.C., G.M. Rego, C.A. Santos, A.S. Peixoto, P.A. Melo Filho, and T.M.G. Moraes. 2006. Recomendações técnicas para o cultivo do amendoim em pequenas propriedades agrícolas do Nordeste brasileiro. Circular Técnica No 102. 7 p. Embrapa Algodão, Campina Grande, Paraíba, Brasil.

SAS Institute. 2000. SAS/STAT User's guide. Version 11. Vol. 1. 9876 p. SAS Institute, Cary, North Carolina, USA.

Sedgley, R.H. 1991. An appraisal of the Donald ideotype after 21 years. Field Crops Research 26:96-112.

Swamy, M.B.P., H.D. Upadhyaya, and P.V.K. Goudar, B.Y Kullaiswamy, and S. Singh. 2003. Phenotypic variation for agronomic characteristics in a groundnut core collection for Asia. Field Crops Research 84:359-371.

Valls, J.F.M. 2005. Recursos genéticos do gênero Arachis. p. $47-$ 69. In Santos, R.C. (ed.) O agronegócio do amendoim no Brasil. Embrapa Algodão, Campina Grande, Paraíba, Brasil.

Vieira, E.A., F.I.F. Carvalho, A.C. Oliveira, G. Benin, C. Lorencetti, P.D. Zimmer, et al. 2006. Use of nonparametric selection indexes in studies of adaptability and stability of oat cultivars. Crop Breeding and Applied Biotechnology 6:95-103.

Wricke, G., and W.E. Weber. 1986. Quantitative genetics and selection in plant breeding. 406 p. Walter de Gruyter, New York, USA.

Yang, R.C. 2009. When is early generation selection effective in selfpollinated crops? Crop Science 49:2065-2079. 